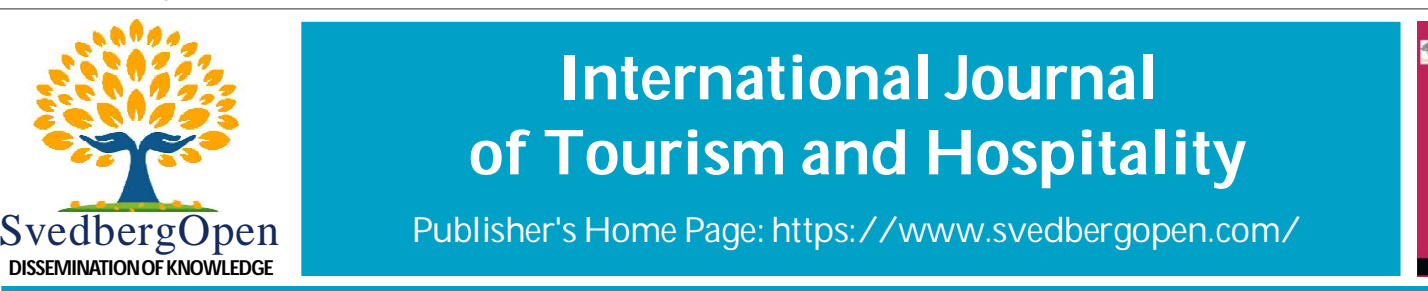

\title{
Assessing the Level of Environmental Awareness and Attitudes of Students in Bulacan State University- Hagonoy Campus During Pandemic
}

\author{
Maybelle N. Dela Cruz ${ }^{1 *}$ and Virginia Natividad-Franco ${ }^{2}$ \\ ${ }^{1}$ Bulacan State University, City of Malolos, Bulacan, Philippines. E-mail: maybelle.delacruz@bulsu.edu \\ ${ }^{2}$ Bulacan State University, City of Malolos, Bulacan, Philippines. E-mail: virginia.franco@bulsu.edu
}

\section{Article Info}

Volume 1, Special Issue 1, December 2021 Received : 09 August 2021

Accepted : 21 November 2021

Published : 05 December 2021

https://doi.org/10.51483/IJTH.1.S1.2021.S8-S16

\begin{abstract}
The study aimed to determine students' level of environmental awareness and attitudes through environmental education. The study utilized a mixed-method type of research. The study's respondents are the 258 students from BS Hospitality Management, and Tourism Management enrolled in the $2^{\text {nd }}$ semester of the SY 2020-2021. The survey instrument with 36 questions on environmental awareness and attitudes was adopted from the study of Bozoglu et al. (2016). Likewise, open-ended questions about the problems encountered about the environment in google forms were also sent via messenger. Students' overall level of environmental awareness got a weighted mean of 3.38 with a verbal interpretation of moderately aware. The statement which got the highest mean is Environmental activities help raise awareness of environmental issues. This garnered a mean of 4.42, with a verbal interpretation of aware. It also means that students are mindful that environmental issues are addressed through activities in school, such as cleaning brigade and tree planting. Furthermore, the environmental attitude of students is interpreted as agree with a weighted mean of 3.79. It means that the majority of the students adhere to the outcomes of environmental education. Regarding the problems encountered about the environment during the Pandemic, the most common responses were the heavy floods, slow or almost no internet connection, garbage in areas, noisy surroundings which affect the study, and the lack of discipline. However, some programs and activities to respond to the issues were suggested to enhance students' awareness of environmental education and create a more helpful outlook.

Keywords: Environment, Awareness, Attitudes, Hospitality and Tourism Management

(C) 2021 Maybelle N. Dela Cruz and Virginia Natividad-Franco. This is an open access article under the CC BY license (https://creativecommons.org/licenses/by/4.0/), which permits unrestricted use, distribution, and reproduction in any medium, provided you give appropriate credit to the original author(s) and the source, provide a link to the Creative Commons license, and indicate if changes were made.
\end{abstract}

\section{Introduction}

The Covid-19 Pandemic has become a significant public health concern worldwide. Hallema et al. (2020) emphasized that the environmental responses to the economic slowdown triggered by the Pandemic resulted in a negative effect on human beings and organizations on the environment. However, Sarkis et al. (2020) highlighted that the Coronavirus outbreak also has positive environmental consequences: significant reductions in air pollution due to the large-scale slowdown in economic activity.

\footnotetext{
* Corresponding author: M aybelle N. D ela Cruz, Bulacan State U niversity, City of M alolos, Bulacan, Philippines.

E-mail: maybelle.delacruz@bulsu.edu
}

2709-9768/@ 2021. Maybelle N. Dela Cruz and Virginia Natividad-Franco. This is an open access article distributed under the Creative Commons Attribution License, which permits unrestricted use, distribution, and reproduction in any medium, provided the original work is properly cited. 
The UN environment reckoned that environmental education might contribute to such a relevant issue by improving quality education and environmental awareness. It is a pedagogical field that promotes the balance between humanity and nature through interdisciplinary studies and hands-on practices that should be present at all educational levels to generate sustainable benefits for society.

The environment is defined as all factors affecting an individual or society's physical, biological, socio-psychological, socioeconomic, and cultural lives. The rising concern regarding environmental issues and their effects on general awareness is one of the most noticeable recent decades (Sivamoorthy et al., 2013). The threat of environmental problems should no longer be underrated. Rogayan (2019) restated that the Earth is now suffering from innumerable afflictions caused by egregious human activities that were relentlessly shedding the ecology. The challenge for a day to day is to take the roll of action and change towards a common cause in preserving life on earth.

In the Philippines, as stated in the Republic Act 9512 series of 2008, the Department of Education (DepEd), the Commission on Higher Education (CHED), and the Technical Education and Skills Development Authority (TESDA), in coordination with the Department of Environment and Natural Resources (DENR), the Department of Science and Technology (DOST) and other relevant agencies, in consultation with experts on the environment and the academe, lead the implementation of public education and awareness programs on environmental protection and conservation through collaborative interagency and multi-sectoral effort at all levels.

Environmental problems are being battered with more university education in the long run since universities teach young groups, expected to be the future leaders in many different areas in the society and the decision-makers. Thus their students are expected to deal with sustainability issues in their personal and professional lives (Bozoglu et al., 2016).

Universities have the accountability to prepare their graduates for preserving the environment. Every department is related to the environment, and their graduates' professional activities can somehow affect the environment. Hence, every department should prepare responsible graduates for a more livable environment. The emerging interest of universities in increasing the consciousness of environmental values makes it necessary to explore the students' environmental awareness, Attitude, and behavior (Bozoglu et al., 2016). The growth of environmental issues has produced many studies with students explaining the distinction between and among each other's knowledge, awareness, attitudes, and behaviors toward the environment.

Therefore, the researchers aimed to determine the environmental awareness, attitudes, and problems encountered by students in one of the top-performing schools in the province-the Bulacan State University-Hagonoy Campus. BulSU-HC is a nature-friendly school surrounded by trees and plants, which gives a relaxing environment for the students and teachers. In 1994, the Municipality of Hagonoy had donated approximately 8.5 hectares of land located at Iba-Carillo, Hagonoy, Bulacan to address the need of Bulacan State University (BulSU-HC). In June 2011, BulSU-HC became fully operational, offering four courses, such as Bachelor of Elementary Education - Generalist, Bachelor of Science in Hotel and Restaurant Management, Bachelor of Science in Information Technology, and General Engineering. The following year other courses like Bachelor of Science in Tourism Management, Bachelor of Science in Criminology, and the Certificate in Two-Year Industrial Technology major in Food Technology and Computer Technology were also offered.

In sustaining a fine-looking environment, it is just proper to teach the students about the environment; thus, the present endeavor will assess the level of environmental awareness and attitudes of BulSU students. Through environmental education and awareness, the researchers believe that the students' attitudes can demonstrate practices that care for the environment. Hence, students should acquire an appropriate range of attention and perspectives about the atmosphere while they were in school to achieve a critical judgment.

\section{Objectives of the Study}

1. To determine the environmental awareness of students at Bulacan State University.

2. To determine the environmental attitudes of students at Bulacan State University.

3. To identify the problems encountered regarding the environment during the pandemic.

4. To identify possible solutions to the environmental problems and enhance the environmental awareness and attitudes of students. 


\section{Literature Review}

Environmental Education: Environmental education is a progression on the people's knowledge, awareness about the environment, and associated issues develop the necessary skills and expertise to address the challenges and foster attitudes, motivations, and commitments to make informed decisions responsible action (Sola, 2014). Environmental education is the learning activities in the environmental field organized by all levels of education (Prihantoro, 2015). It is predicted to change the behavior and patterns of public view towards positively associated environmental concerns and foster a love for the environment early on.

Also, it is vital to motivate students' perceptions to upkeep policies and programs that support efficient use of resources and implement actions, reducing environmental damage, resulting in sustainable development (Anbalagan and Shanthi, 2015). It is considered helpful to have a good quality of life to developing ideas and practices for maintaining a sustainable environment (Laiphrakpam et al., 2019). Likewise, environmental education can increase the knowledge and awareness of the students that can lead to behavioral change.

Sola (2014) stated that environmental education can be incorporated into prevailing disciplines, or it can be imparted as a subject in its own right. It can be taught as early as primary school as well as in adult education programs.

As stated in Republic Act 9512, An Act to promote Environmental Awareness through Environmental Education and for other Purposes. Yildiz and Budur (2019) cited that school gardens are the best places to educate and inform learners of responsibility in arranging, organizing, and decorating the fields.

Henceforth, introducing environmental issues to students to integrate environmentally related subjects into traditional course offerings can be another solution (Wagner, 1997). Likewise, outdoor activities such as field trips, having a picnic in green areas, walking in nature, or trekking and hiking activities will help educators and students with opportunities to absorb environmental issues, and these techniques are recognized as effective means of teaching awareness of the environment (Palmberg and Kuru, 2000).

Furthermore, environmental in-service training programs for teachers delivered at centers for interdisciplinary environmental education are considered important priorities (Laiphrakpam et al., 2019).

Environmental Awareness: Environmental awareness can be heightened by education at different levels to improve people's knowledge and attitudes. It is expected that this will boost their readiness to take individual and collective action, alleviate environmental problems, and promote environmental conservation (UNESCO 1980; Laiphrakpam et al., 2019). It includes understanding the main relationships between nature and human beings and initiatives for protecting the natural and future environment. Many studies have pointed out that environmental awareness is closely related to human perception of environmental problems, inter-dependence and relations between humans and nature, people's behavior, and Attitude towards the environment (Yingchao et al., 2011).

According to Li (2018), environmental awareness involves absorbing, understanding, storing, and organizing information about the environment. It does not merely involve physical elements of the environment, per se, but also emotions, experiences, perceptions, and attitudes. People's awareness is recognized as a powerful tool in protecting the environment, and information through education decidedly affects behavior (as cited in Gonzaga, 2016).

Environmental Attitude: Any object outside of self exists in the individual's environment, so all attitudes except those beliefs about self could be correctly called environmental attitudes (Heberlein, 1981). Environmental attitudes have been defined as "the collection of beliefs, affect, and behavioral intentions a person holds regarding environmentally related activities or issues" (Schultz et al., 2004). Although this three-component model remains the traditional view of attitude structure, new theoretical approaches conceptualize attitudes as evaluative tendencies that can be inferred from and influence beliefs, affect, and behavior (Milfont and Duckitt, 2010).

Students have always played an active part in the events leading to the development of environmental awareness. Thus, many studies have been carried out to understand the environmental attitudes and behaviors of the students. Besides, the fact that the students will be the ones who will manage and consume the future resources has been effective in doing studies related to the students (Müderrisoglu and Altanlar, 2011).

As to Boeve-de Pauw and Van Petegem (2010), researchers have demonstrated that younger people hold more environmentally positive attitudes than older people. In some literature, age appears to correlate to environmental attitudes (Arcury, 1990). Young people are believed to be less integrated into society than are adults and will thus more readily criticize industrial and governmental policies. 
Feinberg and Willer (2013) cited in their study that a specific to environmental attitudes, past research suggests that perceiving environmental issues in moral terms is related to the valence and strength of individuals' environmental attitudes.

\section{Methodology}

The study utilized the mixed-methods type of research. Mixed-methods research integrates qualitative and quantitative data within a single study (Halcomb and Hickman, 2015). Mixed methods take advantage of the strengths of both qualitative and quantitative procedures while improving on their weaknesses to provide an integrated, comprehensive understanding of the topic under investigation (Scammon et al., 2013).

The study's respondents are the Bachelor of Science in Hospitality and Restaurant Management and Bachelor of Science in Tourism Management students. From the 654 total enrolled students for the $2^{\text {nd }}$ semester of the school year 2020-2021, the researcher came up with a sample of 258 as computed using the sample size calculator by Raosoft, Inc.

The study used a validated survey instrument adapted from Bozoglu et al. (2016) entitled Factors Affecting The Students' Environmental Awareness, Attitudes, And Behaviors In Ondokuz Mayis University, Turkey. The instrument is composed of two parts. The first part measures the level of environmental awareness of students, and the second part is about the status of students' environmental attitudes. The survey questionnaire was disseminated via messenger.

The Likert scale measurement was used for every statement of environmental awareness on a 5-point scale. The verbal interpretation is as follows, 5 - very much aware, 4 - aware, 3 - moderately aware, 2 - slightly aware, and 1 unaware. For the Attitude, Likert scale interpretations are as follows, 5 - strongly agree, 4 - agree, 3 - neutral, 2 disagree and 1 - strongly disagree. Descriptive statistics such as frequency, mean and weighted mean were used in the study.

\section{Results and Discussion}

Table 1 presents the level of environmental awareness of students in Bulacan state University-Hagonoy campus.

Table 1: Level of Environmental Awareness of Students in Bulacan State University

\begin{tabular}{|c|c|c|c|c|c|c|c|c|}
\hline No. & Indicators & 1 & 2 & 3 & 4 & 5 & Mean & Interpretation \\
\hline 1 & $\begin{array}{l}\text { Creating environmentally conscious } \\
\text { individuals is compulsory for future } \\
\text { generations to live in a healthy and } \\
\text { safe environment }\end{array}$ & 0 & 5 & 31 & 109 & 113 & 4.28 & Aware \\
\hline 2 & $\begin{array}{l}\text { Using insecticides and herbicides for } \\
\text { agriculture is not harmful to the } \\
\text { environment }\end{array}$ & 15 & 41 & 89 & 89 & 24 & 3.26 & Moderately Aware \\
\hline 3 & $\begin{array}{l}\text { Environmental activities help raise } \\
\text { awareness of environmental issues }\end{array}$ & 1 & 1 & 22 & 98 & 134 & 4.42 & Aware \\
\hline 4 & $\begin{array}{l}\text { Environmental protection is a } \\
\text { constitutional obligation }\end{array}$ & 1 & 3 & 28 & 114 & 112 & 4.29 & Aware \\
\hline 5 & $\begin{array}{l}\text { Field activities related to the } \\
\text { environment are a waste of time; } \\
\text { class activities are important. }\end{array}$ & 62 & 67 & 52 & 47 & 30 & 2.67 & Moderately Aware \\
\hline 6 & $\begin{array}{l}\text { If universities carry out more } \\
\text { activities on the environment, } \\
\text { it will help better understand } \\
\text { environmental issues }\end{array}$ & 2 & 5 & 40 & 102 & 109 & 4.21 & Aware \\
\hline 7 & $\begin{array}{l}\text { Protecting the environment is a duty } \\
\text { of the state, not people. }\end{array}$ & 45 & 58 & 80 & 41 & 33 & 2.84 & Moderately Aware \\
\hline
\end{tabular}




\begin{tabular}{|c|c|c|c|c|c|c|c|c|}
\hline No. & Indicators & 1 & 2 & 3 & 4 & 5 & Mean & Interpretation \\
\hline 8 & Human mistreat the environment & 4 & 11 & 91 & 83 & 69 & 3.78 & Aware \\
\hline 9 & $\begin{array}{l}\text { Environmental education activities } \\
\text { are useful only for children }\end{array}$ & 54 & 76 & 49 & 47 & 31 & 2.71 & Moderately Aware \\
\hline 10 & $\begin{array}{l}\text { A squatter is not an environmental } \\
\text { problem }\end{array}$ & 46 & 65 & 84 & 43 & 19 & 2.70 & Moderately Aware \\
\hline 11 & Environmental problems are exaggerated & 35 & 38 & 87 & 67 & 29 & 3.07 & Moderately Aware \\
\hline 12 & $\begin{array}{l}\text { Rapid population growth is a serious } \\
\text { environmental problem }\end{array}$ & 4 & 5 & 60 & 121 & 67 & 3.94 & Aware \\
\hline 13 & $\begin{array}{l}\text { Air, water and soil are inexhaustible } \\
\text { resources }\end{array}$ & 13 & 19 & 105 & 85 & 36 & 3.43 & Moderately Aware \\
\hline 14 & $\begin{array}{l}\text { The necessity of using water filters at } \\
\text { homes is an indicator of water pollution }\end{array}$ & 9 & 33 & 97 & 87 & 32 & 3.39 & Moderately Aware \\
\hline 15 & $\begin{array}{l}\text { Being sensitive to environmental } \\
\text { problems is not an obstacle for the } \\
\text { development of a country }\end{array}$ & 14 & 24 & 98 & 97 & 25 & 3.37 & Moderately Aware \\
\hline 16 & $\begin{array}{l}\text { Western people invented the idea of } \\
\text { environmental protection to prevent } \\
\text { the development of developing countries }\end{array}$ & 13 & 13 & 124 & 77 & 30 & 3.38 & Moderately Aware \\
\hline 17 & $\begin{array}{l}\text { I increasingly need more information } \\
\text { about the effects of our activities on } \\
\text { the environment }\end{array}$ & 2 & 6 & 62 & 125 & 61 & 3.93 & Aware \\
\hline 18 & $\begin{array}{l}\text { There is no desertification problem } \\
\text { in Bulacan State University }\end{array}$ & 10 & 25 & 138 & 66 & 17 & 3.21 & Moderately Aware \\
\hline 19 & $\begin{array}{l}\text { Immigration affects negatively } \\
\text { environmental problems }\end{array}$ & 32 & 89 & 115 & 15 & 5 & 3.50 & Moderately Aware \\
\hline 20 & $\begin{array}{l}\text { Delivering environmental education } \\
\text { does not help solving environmental } \\
\text { problems }\end{array}$ & 50 & 81 & 64 & 48 & 15 & 2.60 & Moderately Aware \\
\hline 21 & $\begin{array}{l}\text { No international institution or } \\
\text { organization should intervene in } \\
\text { using natural resources. }\end{array}$ & 9 & 29 & 135 & 59 & 26 & 3.25 & Moderately Aware \\
\hline 22 & $\begin{array}{l}\text { There have not been enough protest } \\
\text { meetings for protecting the environment } \\
\text { at Bulacan State University }\end{array}$ & 8 & 23 & 122 & 84 & 21 & 3.34 & Moderately Aware \\
\hline 23 & $\begin{array}{l}\text { The increase in natural gas usage at } \\
\text { Bulacan State University did not } \\
\text { contribute to the air pollution problem }\end{array}$ & 21 & 40 & 124 & 56 & 17 & $\mathbf{3 . 0 3}$ & Moderately Aware \\
\hline 24 & $\begin{array}{l}\text { The university is not sensitive enough } \\
\text { towards environmental problems }\end{array}$ & 21 & 33 & 126 & 60 & 18 & 3.08 & Moderately Aware \\
\hline 25 & $\begin{array}{l}\text { Environmental education is not } \\
\text { enough in Bulacan State Univesity }\end{array}$ & 15 & 63 & 102 & 54 & 23 & 3.03 & Moderately Aware \\
\hline 26 & $\begin{array}{l}\text { People who spit on or litter the } \\
\text { ground should have interfered. }\end{array}$ & 13 & 46 & 119 & 61 & 19 & 3.10 & Moderately Aware \\
\hline & Weighted Mean & & & & & & 3.38 & Moderately Aware \\
\hline
\end{tabular}


As shown on the table, the indicator with the highest mean is the statement that states that Environmental activities help raise awareness of environmental issues. This garnered a mean of 4.42, with a verbal interpretation of aware. It also means that environmental issues are being addressed through environmental activities in school, such as cleaning brigade and tree planting. Moreso, outdoor activities such as field trips, having a picnic in green areas, walking in nature, or trekking and hiking activities will help educators and students with opportunities to absorb environmental issues, and these techniques are recognized as effective means of teaching awareness of the environment (Palmberg and Kuru, 2000).

On the other hand, the statement, Delivering environmental education does not help to solve environmental problems, got the lowest mean of 2.60, which was interpreted as moderately aware. Perhaps, simply bringing the idea of environmental education without proper action couldn't really solve the environmental problems. As Laiphrakpam et al. (2019) stated, environmental education includes understanding the main relationships between nature and human beings and protecting the natural and future environment. It is considered helpful to have a good quality of life to developing ideas and practices for maintaining a sustainable environment.

However, the overall environmental awareness of BulSU-HC students obtained a weighted mean of 3.38 with the verbal interpretation of moderately aware. This indicates that the students are just in the middle of their knowledge regarding environmental awareness.

Though people's awareness is recognized as a powerful tool in protecting the environment, and information through education decidedly affects behavior (as cited in Gonzaga, 2016).

Likewise, Yingchao et al. (2011) stated that many studies have pointed out that environmental awareness is closely related to factors such as; human perception of environmental problems, inter-dependence, and relations between humans and nature' behavior and attitude towards the environment. Perhaps these students differ in their perceptions regarding environmental problems and the like.

Table 2 presents the level of environmental attitudes of students in Bulacan state University-Hagonoy campus.

Table 2: Level of Environmental Attitudes of Students in Bulacan State University

\begin{tabular}{|c|c|c|c|c|c|c|c|c|}
\hline No. & Indicators & 1 & 2 & 3 & 4 & 5 & Mean & Interpretation \\
\hline 27 & $\begin{array}{l}\text { We should try to protect Earth's plants } \\
\text { and animals, even though it is expensive }\end{array}$ & 4 & 9 & 106 & 91 & 48 & 3.66 & Agree \\
\hline 28 & $\begin{array}{l}\text { Courses of the environment must } \\
\text { be practical. }\end{array}$ & 2 & 4 & 38 & 99 & 115 & 4.24 & Agree \\
\hline 29 & $\begin{array}{l}\text { People who pollute the environment } \\
\text { should be fined. }\end{array}$ & 1 & 4 & 76 & 110 & 65 & 3.91 & Agree \\
\hline 30 & $\begin{array}{l}\text { Newspapers, magazines, and televisions } \\
\text { should make more programs about } \\
\text { environmental issues. }\end{array}$ & 36 & 30 & 62 & 74 & 56 & 3.32 & Agree \\
\hline 31 & $\begin{array}{l}\text { I love to visit recreation areas outside } \\
\text { of the city. }\end{array}$ & 1 & 2 & 45 & 100 & 110 & 4.22 & Agree \\
\hline 32 & $\begin{array}{l}\text { Courses about the environment should } \\
\text { be compulsory. }\end{array}$ & 0 & 1 & 65 & 104 & 87 & 4.08 & Agree \\
\hline 33 & $\begin{array}{l}\text { Regardless of their position, any } \\
\text { country engaging in nuclear testing } \\
\text { should be protested. }\end{array}$ & 4 & 7 & 101 & 106 & 40 & 3.66 & Agree \\
\hline 34 & $\begin{array}{l}\text { I think I am very sensitive about } \\
\text { environmental issues. }\end{array}$ & 4 & 11 & 113 & 92 & 38 & 3.58 & Agree \\
\hline 35 & $\begin{array}{l}\text { I prefer the option of highway } \\
\text { construction to the protection } \\
\text { of plant species. }\end{array}$ & 2 & 10 & 97 & 106 & 41 & 3.68 & Agree \\
\hline 36 & $\begin{array}{l}\text { For my country, I prefer technological } \\
\text { development to noise pollution. }\end{array}$ & 16 & 19 & 91 & 86 & 46 & 3.50 & Neutral \\
\hline & Weighted Mean & & & & & & 3.79 & Agree \\
\hline
\end{tabular}


Among the indicators of environmental attitudes, the statement Courses of the environment must be practical got the highest mean of 4.24 with a verbal interpretation of agree. This means that students want a concrete application of environmental education. Like what Yildiz and Budur (2019) cited, introducing environmental issues to students to integrate environmentally related subjects into traditional course offerings can be another solution (Wagner, 1997). Likewise, outdoor activities can also be a helpful technique to increase students' environmental awareness and address environmental issues. On the other hand, the statement Newspapers, magazines, and televisions should make more programs about environmental issues, got the lowest mean of 3.32 .

Students nowadays are keener to emerging technologies like smartphones and computers. Emerging technologies are the latest innovations that are developed for practical application (Martin, 2015). It is easy for these young generations to read and browse news about these technologies' current issues. Furthermore, students' environmental attitudes in BulSU-HC garnered a weighted mean of 3.79 with a verbal interpretation of agree. This means that these students favorably agreed on the environmental attitudes indicators.

Table 3: Problems Encountered by Students About Environment During the Pandemic

\begin{tabular}{|ll|c|c|}
\hline & Problems & Frequency & Percentage \\
\hline $\mathbf{1}$ & Heavy flood due to rain and high tide & 22 & 0.22 \\
\hline $\mathbf{2}$ & Slow internet connection & 18 & 0.18 \\
\hline $\mathbf{3}$ & Garbage (added face mask, face shield, etc.) & 8 & 0.17 \\
\hline $\mathbf{4}$ & Heavy noise outside (can't focus on studying) & 7 & 0.08 \\
\hline $\mathbf{5}$ & Lack of discipline & 28 & 0.07 \\
\hline $\mathbf{6}$ & Others & $\mathbf{1 0 0}$ & $\mathbf{1 0 0 \%}$ \\
\hline
\end{tabular}

Upon analyzing the different problems encountered by students about the environment during the pandemic, the top issue was the heavy floods due to rain and high tide. The town of Hagonoy is a catch basin of water from nearby areas. The high tide causes a surge in the majority of the places; added to it is the heavy rain-the second problem about the slow internet connection. The third problem is the ton of garbage. The disposed of face masks, face shields, and the like added to the trash found in the community. The next issue encountered regarding the environment is the heavy noise outside, which enables them not to study well and no focus. The last one among the issues raised is the lack of discipline among people. Most of them are not following health protocols, which makes the pandemic longer to conquer.

Table 4: Proposed Program and Solutions to the Environmental Issues and Enhance the Awareness and Attitudes Students

\begin{tabular}{|c|c|c|}
\hline & Activities & Objectives \\
\hline 1 & Environmental Education Symposium & To increase the environmental awareness of students. \\
\hline 2 & Tree Planting & To improve the air quality by filtering harmful dust and pollutants. \\
\hline 3 & $\begin{array}{l}\text { Waste Management (Apply the } 3 \mathrm{R} \text { Approach } \\
\text { (Reuse, Reduce, and Recycle) }\end{array}$ & $\begin{array}{l}\text { To properly utilized functional waste materials for economic } \\
\text { purposes and disposed of unnecessary ones. }\end{array}$ \\
\hline 4 & Clean and Green Program & To sustain the cleanliness in the environment \\
\hline 5 & Drainage System, Digging of River & To prevent flooding in almost all areas \\
\hline & $\begin{array}{l}\text { Inclusion of an Elective Subject on } \\
\text { Environmental Education in the Curriculum }\end{array}$ & $\begin{array}{l}\text { To inculcate and apply in practice the knowledge in } \\
\text { environmental education }\end{array}$ \\
\hline
\end{tabular}




\section{Conclusion}

This study aimed to determine students' environmental awareness and attitudes in Bulacan State University-Hagonoy Campus. It also aimed to identify the problems encountered by students regarding the environment and proposed programs to enhance the environmental awareness and attitudes and solutions to the environmental issues as experienced by students during the pandemic.

The study is supported by previous studies indicating awareness and their attitudes towards environmental education. The students are found to have a moderate awareness of environmental education. Regarding the environmental attitudes, the students agreed on the given indicators. In terms of the environmental issues raised by students, heavy floods, slow internet, garbage, heavy noise, and lack of discipline are the topmost problems encountered by the students.

After analyzing the given result, the researchers suggested activities that will enhance the students' environmental awareness and create a positive attitude towards environmental education.

\section{References}

Arcury, T. (1990). Environmental Attitude And Environmental Knowledge. Human Organization, 49(4), $300-304$.

Anbalagan, G. and Shanthi, K. (2015). A Study on Environmental Awareness and Related Practices Among the High School Students at Madurai District, Tamil Nadu, Indian Streams Research Journal, 5.

Boeve-de Pauw, J. and Van Petegem, P. (2010). A Cross-National Perspective on Youth Environmental Attitudes. The Environmentalist, 30(2), 133-144.

Bozoglu, M., Bilgic, A., Topuz, B.K. and Ardali, Y. (2016). Factors Affecting the Students' Environmental Awareness, Attitudes and Behaviors in Ondokuz Mayis University, Turkey. Fresenius Environmental Bulletin, 25(4), 12431257.

Feinberg, M. and Willer, R. (2013). The Moral Roots Of Environmental Attitudes. Psychological Science, 24(1), 56-62.

Gonzaga, M.L. (2016). Awareness and Practices in Green Technology of College Students. Applied Mechanics and Materials, 848, 223-227. doi:10.4028/www.scientific.net/AMM.848.223

Halcomb, E.J. and Hickman, L. (2015). Mixed Methods Research.

Hallema, D.W., Robinne, F.N. and McNulty, S.G. (2020). Pandemic Spotlight on Urban Water Quality. Ecological Processes, 9(1), 1-3.

Heberlein, T.A. (1981). Environmental Attitudes. Zeitschrift für Umweltpolitik, 4, 241-270.

Laiphrakpam, M., Aroonsrimorakot, S. and Shanker, A.R. (2019). Environmental Education And Awareness Among Students In India, Japan And Thailand For Sustainable Development. Interdisciplinary Research Review, 14(2), 48-53.

Li, Yang (2018). Study of the Effect of Environmental Education on Environmental Awareness and Environmental Attitude Based on Environmental Protection Law of the People's Republic of China.

Milfont, T.L. \& Duckitt, J. (2010). The Environmental Attitudes Inventory: A Valid And Reliable Measure to Assess the Structure of Environmental Attitudes. Journal of Environmental Psychology, 30(1), 80-94.

Müderrisoglu, H. and Altanlar, A. (2011). Attitudes and Behaviors of Undergraduate Students Toward Environmental Issues. International Journal of Environmental Science \& Technology, 8(1), 159-168.

Palmberg, I.E. and Kuru, J. (2000). Outdoor Activities As A Basis For Environmental Responsibility. Journal of Environmental Education, 31(4), 32-37.

Prihantoro, C.R. (2015). The Perspective of the Curriculum in Indonesia on Environmental Education. International Journal Of Research Studies in Education, 4(1), 77-83.

Republic Act 9512. (2008). An Act to Promote Environmental Awareness Through Environmental Education and for Other Purposes. Retrieved on February 2, 2017 from https://goo.gl/MmmiUt

Sarkis, J., Cohen, M.J., Dewick, P. and Schröder, P. (2020). A Brave New World: Lessons from the Covid-19 Pandemic for Transitioning to Sustainable Supply And Production. Resources, Conservation, and Recycling, 159, 104894. 
Scammon, D.L., Tomoaia-Cotisel, A., Day, R.L., Day, J., Kim, J., Waitzman, N.J., Farrell, T.W. and Magill, M.K. (2013). Connecting the Dots and Merging Meaning: Using Mixed Methods to Study Primary Care Delivery Transformation. Health Services Research, 48, 2181-2207

Sola, A.O. (2014). Environmental Education and Public Awareness. Journal of Educational and Social Research, 4(3), 333-337.

Schultz, P.W., Shriver, C., Tabanico, J.J. and Khazian, A.M. (2004). Implicit Connections With Nature. Journal of Environmental Psychology, 24, 31-42.

Sivamoorthy, M., Nalini, R. and Satheesh Kumar, C. (2013). Environmental Awareness and Practices among College Students. International Journal of Humanities and Social Science Invention, 2(8), 11-15.

UNESCO (1980). Environmental Education in the Light of the Tbilisi Conference. Paris: UNESCO.

Wagner, E. (1997). Environmental Attitudes in the Elementary Grades: A Bibliographic Essay. (ERIC Document Reproduction Service No ED 412 075).

Yildiz, Y. and Budur, T. (2019). Introducing Environmental Awareness to College Students with Curricular and Extracurricular Activities. International Journal of Academic Research in Business and Social Sciences, 9(3), 666-675.

Yingchao, L., Masahiko, F. and Wang, P. (2011). Study on Comparison of Citizens' Environmental Awareness Among Four Cities in China and Japan. Management Science and Engineering. 5, 126-131.

Cite this article as: Maybelle N. Dela Cruz and Virginia Natividad-Franco (2021). Assessing the Level of Environmental Awareness and Attitudes of Students in Bulacan State University- Hagonoy Campus During Pandemic . International Journal of Tourism and Hospitality. 1(S1), S8-S16. https://doi.org/10.51483/IJTH.1.S1.2021.S8-S16. 